\title{
How secondary social studies teachers define literacy and implement literacy teaching strategies: A qualitative research study
}

\author{
Joshua L. Kenna - University of Tennessee, USA \\ William B. Russell III* - University of Central Florida, USA \\ Bonnie Bittman - University of Central Florida, USA
}

\begin{abstract}
Educational standards have changed rapidly and drastically in the past several years, including an increased focus on literacy within the social studies. Using data from a four-month qualitative study, this article examines how seven secondary social studies teachers talked about and defined literacy, and how those perspectives informed their pedagogical choices. The enquiry is a response to two areas: first, the many and varied definitions of literacy found in the literature (for example, content area literacy, multiliteracies and media literacy); and second, the added attention given to disciplinary literacy in the widely adopted Common Core State Standards. We found these teachers had four common elements when talking about and defining literacy: (1) reading comprehension; (2) writing fluidity; (3) skills; and (4) vocabulary. Additionally, we discovered that teachers discussed using four kinds of literacy teaching strategies: (1) content area reading strategies; (2) disciplinary reading strategies; (3) writing strategies; and (4) dialogue strategies. However, we determined that the teachers' theoretical understanding of literacy had only minor influence on their pedagogical choices. Instead, we found overarching assessments such as an end-of-course, advanced placement or state-wide reading exam had greater influence on the pedagogical choices the teachers made. The findings suggest that the effort to expand literacy instruction into the disciplines is still a work in progress, which falls in the hands of teacher educators and professional development providers.
\end{abstract}

Keywords: social studies; literacy; education; teaching; instruction

\section{Introduction}

The National Council for the Social Studies (NCSS, 1994: n.p.), the leading social studies organization in the United States, defines social studies as 'the integrated study of the social sciences and humanities to promote civic competence'. The same document states that, 'The primary purpose of social studies is to help young people make informed and reasoned decisions for the public good as citizens of a culturally diverse, democratic society in an interdependent world'. Yet, it is hard to envision students developing the knowledge and skills essential to participate in the decision-making practices of a multicultural democratic society if they are ill equipped to critically read a wide variety of texts (Reidel and Draper, 2011a). A strong democracy depends not only on the ability of the people to read and comprehend various texts, but also on 
their ability to critique and question those texts ( $O^{\prime}$ Quinn, 2005). Therefore, literacy is necessary for the fulfilment of the goal and purpose of social studies. Furthermore, at the disciplinary level (for disciplines such as history, geography, economics and government) literacy skills are inherently vital for learning and retaining content knowledge.

Poor literacy skills among K-12 students - those in their final year of schooling have long been documented in the United States. According to the National Assessment of Educational Progress 2013 national report card on reading, approximately 64 per cent of eighth-grade students tested were at or below the Basic Performance Level (NCES, 2013). The 2014 US history report showed that approximately 82 per cent of eighth-grade students were at or below the Basic Performance Level (NCES, 2015). There were similar results when examining other social studies disciplines, such as civics (approximately 77 per cent), geography (approximately 73 per cent) and economics (approximately 58 per cent), which were administered to students in Grades 4, 8 and 12 respectively (NCES, 2015, 2007). The scores indicate that a large majority of students have 'partial mastery of prerequisite knowledge and skills' in literacy and social studies content (NCES, 2011: 6).

In the summer of 2010, the Common Core State Standards (CCSS), a stateled effort launched and funded by the National Governors Association, the Council of Chief State School Officers and several other not-for-profit organizations, were released for mathematics and English language arts (ELA) (Kenna and Russell, 2015). Within the ELA standards there was a portion for social studies titled Common Core State Standards for English Language Arts and Literacy in History/Social Studies. The social studies portion of the CCSS was created not only with the aim of transforming teaching but also with the hope of developing and improving the disciplinary literacy skills in students (National Governors Association Center for Best Practices and Council of Chief State School Officers, 2010).

The term and concept of disciplinary literacy, however, is rather new. In fact, over the decades several theories on literacy have been formulated; as a result, the 'word literacy has undergone numerous changes in the broad array of concepts it has denoted' (McKenna and Robinson, 1990: 184; emphasis in original). Therefore, the purpose of this study was to uncover how social studies teachers define literacy and implement literacy teaching strategies. The study utilized a qualitative research design. Literature from scholars and specialists in literacy education and social studies education is referenced to establish a definition of literacy and its numerous changes. The traditional positioning of literacy instruction in social studies education is also explored.

\section{Literature review}

\section{Defining literacy}

According to Kane (2007), literacy has traditionally been referred to as simply reading and writing; however, more recently, literacy has taken on a larger context. The Standards for the English Language Arts (National Council of Teachers of English and International Reading Association, 1996: 2) states that literacy includes 'the capacity to accomplish a wide range of reading, writing, speaking, and other language tasks associated with everyday life'. The Standards for the English Language Arts document provides another definition, which states that 'Being literate in contemporary society means being active, critical, and creative users not only of print and spoken language 
but also visual language of film and television, commercial and political advertising, photography, and more' (ibid.: 5). The singular term literacy, then, does not effectively capture the multifaceted elements involved in being literate. As such, many scholars use the term literacies, and have developed theories about multiliteracies and new literacies (Alvermann, 2004; Baildon and Damico, 2011; Cope and Kalantzis, 2000; Harste, 2003; Kane, 2007; New London Group, 1996; Street, 2003). In fact, Alvermann (2004: 227) explains:

A pedagogy of multiliteracies broadens the meaning of text and relates textual reading to oral, aural, tactile, and digital modes of learning as well as to the social skills necessary for communicating and collaborating while engaged in such learning.

Therefore, social studies teachers who wish to adhere to a pedagogy of multiliteracies should have students read from a variety of online texts, such as wikis, blogs, podcasts, social media sites and other websites. Additionally, teachers should have students become designers and contributors of content, and not just consumers (Biswas, 2014).

In addition to accounting for the growing multifaceted elements of literacy, advocates also suggest that literacy is not the sole responsibility of teachers of English language art. This form of literacy is labelled content area literacy, and is often spoken of when discussing literacy education at the secondary level (McKenna and Robinson, 1990; Moje et al., 2004; O'Brien et al., 1995; Readence et al., 2004; Reidel and Draper, 2011a; Shanahan and Shanahan, 2012; Vacca and Vacca, 2008).

Readence et al. (2004) define content area literacy as the level of reading and writing skill necessary to read, comprehend and react to appropriate instructional materials in a given subject area. Vacca and Vacca (2008: 10) write, 'content literacy refers to the ability to use reading, writing, talking, listening, and viewing to learn subject matter in a given discipline'. Shanahan and Shanahan (2012), however, contend that content area literacy is merely a collection of study skills that students use to learn from subject-matter-specific texts. In other words, Shanahan and Shanahan argue that content area literacy teaches learners techniques they might use to make sense of a disciplinary text, such as how to study a history book for an examination. These techniques are often organized into what teachers and readers should do before, during and after reading (LaDuke et al., 2016). For example, some pre-reading strategies that content area literacy advocates stress are: (1) activating prior knowledge; (2) introducing key vocabulary; and (3) making learners aware of metacognitive processes associated with texts and strategies (Vacca and Vacca, 2008).

In contrast to content area literacy, some scholars are advocating for the reconceptualization of literacy learning and instruction at the middle and secondary level with what they call disciplinary literacy (Damico et al., 2009; Moje, 2008; Shanahan and Shanahan, 2008). Shanahan and Shanahan (2012: 8) define disciplinary literacy as:

... an emphasis on the knowledge and abilities possessed by those who create, communicate, and use knowledge within the disciplines ... [Furthermore it] emphasizes the unique tools that the experts in a discipline use to engage in the work of that discipline.

Additionally, Moje (2008: 97) contends that disciplinary literacy is 'a form of critical literacy because it builds an understanding of how knowledge is produced in the disciplines, rather than just building knowledge in the disciplines'. 
Thus, in history classes students are encouraged to read, write and think like a historian. In 1991, Sam Wineburg published a seminal piece that identified particular reading practices of historians (sourcing, contextualizing and corroboration). Additional habits of mind have been identified, such as empathy, perspective taking, and inference making (Nokes, 2013). Moreover, Shanahan et al. (2011) analysed the literacy practices of experts from three disciplines (history, mathematics and chemistry), and found variations of literacy practices within disciplines. For instance, the literacy practice of sourcing (paying close attention to the author, the kind of document and the origin of the document) was identified as an 'explicit and thorough consideration of author perspective' for those in history (Shanahan et al., 2011: 406). Those in chemistry, however, saw the 'use of source as a text selection factor, but not an interpretive one' (ibid.: 406), and the mathematicians made an 'active effort to not use source as an interpretive consideration' (ibid.: 406).

Finally, many scholars have generalized the term 'literacy' to speak of the knowledge of, or ability in, a specific subject or topic, including technological literacy (Ikpeze and Boyd, 2007), historical literacy (Goudvis and Harvey, 2012; Walker, 2006), digital literacy (Shand et al., 2012), media literacy (Bellino, 2008; Mason and Metzger, 2012; Stein and Prewett, 2009) and critical literacy (Reidel and Draper, 2011a; Soares and Wood, 2010). While the definitions of each term are not provided here, they are included as evidence of the fact that literacy has taken on a variety of definitions. As a result of the various definitions of literacy, there are a variety of camps that seem to privilege particular approaches to literacy over others (Fang and Coatoam, 2013; Hynd-Shanahan, 2013), while others advocate for a blending of approaches (LaDuke et al., 2016).

\section{Social studies and literacy}

While there is extensive literature and research on literacy, and ample literature promoting the amalgamation of literacy and social studies, as a whole social studies tends to be devoid of literacy instruction, regardless of the specific definition utilized for literacy (Draper et al., 2005; Moje, 1996; O'Brien and Stewart, 1990; Reehm and Long, 1996; Simonson, 1995). In part, this could be attributed to the fact that many social studies teachers still think of literacy in its most basic form (that is, reading and writing), as they are often overheard saying that they do not teach reading (Hall, 2005; Reidel and Draper, 2011b). According to Moje (2008: 98):

... the failure to successfully teach literacy in secondary schools range from explanations rooted in knowledge, beliefs, or cultural values among teachers and students to the structures of secondary schools and the dominance of subject area norms. Although, my basic premise is that the reason for a lack of integration is that secondary content literacy has focused more on literacy than on the subject areas.

In other words, secondary teachers, including social studies teachers, identify with being experts in their discipline but do not include disciplinary literacy practices as being a part of their expertise (Hall, 2005). Therefore, a dualism exists between literacy and disciplinary knowledge, as disciplinary knowledge 'is frequently conceptualized as an interrelated body of facts, concepts, and processes wherein literacy skills and abilities are incidental' (Draper et al., 2005: 12-13).

Surprisingly, given the various definitions used for literacy, the array of literacy techniques being advocated for, and the dualism that exists between literacy and 
disciplinary knowledge, there is little research in social studies education that addresses how social studies teachers make meaning of literacy, not to mention how those meanings align with their pedagogical choices. Therefore, this research is an initial attempt to address this area of enquiry within the field of social studies education.

\section{The research paradigm}

\section{Research questions}

To understand how seven social studies teachers made meaning of literacy, the following research questions guided this study:

(1) In what ways do secondary social studies teachers define literacy?

(2) How do social studies teachers' definitions of social studies, in relation to literacy, align with their self-reported and observed pedagogical choices?

\section{Conceptual framework}

Since this study analysed how secondary social studies teachers defined literacy and how that definition aligned with their pedagogical choice, we utilized a conceptual framework, Disciplinary Literacy Pedagogical Content Knowledge (Carney and Indrisano, 2013), which emerges from the combined interaction, or blending, of Shulman's $(1986,1987)$ three forms of knowledge (that is, subject matter content knowledge, pedagogical content knowledge and curricular knowledge). Carney and Indrisano (2013), however, suggest that knowledge of the reading process can substitute for the curricular knowledge because a teacher's understanding of the reading process, or process knowledge as they later label it, is fundamental to acquiring knowledge in a domain. In fact, they conclude that when teachers have the capacity to blend domain content, disciplinary pedagogy and process knowledge '[teachers] can provide effective pedagogy, not only for the content, but also for the ways of reading, thinking, and knowing that are germane to a discipline' (ibid.: 47).

According to Carney and Indrisano (ibid.: 43), the process knowledge domain consists of six processes: (1) developing and activating schema; (2) understanding vocabulary and concepts; (3) metacognition; (4) awareness of text structures; (5) adopting a reader's stance; and (6) engagement. While Carney and Indrisano (2013) acknowledge that content area literacy also consists of similar processes, it is the ways in which each discipline utilizes the processes that separate the two.

\section{Research methodology}

\section{Data collection}

The lead author interviewed seven secondary social studies teachers over a three-month period in 2015 using a semi-structured interview process. The interview questions were organized around themes but allowed each teacher's response to guide the interview. The initial questions were developed based on theoretical considerations regarding disciplinary literacy (Damico et al., 2009; Moje, 2008; Shanahan and Shanahan, 2008; Zygouris-Coe, 2012). For example, teachers were asked to describe: (1) their students as readers, writers and discipline thinkers; (2) their students' reading, writing and discipline thinking abilities; (3) their expectations for reading, writing and discipline 
thinking; and (4) what types of texts, strategies and assignments they utilize to have students reach those expectations.

As the teachers answered the questions, the lead author often asked clarifying questions, such as 'tell me more' and 'explain'. The goal was to understand how these teachers talked about literacy so the unseen could be captured (Glesne, 2011). Each social studies teacher was interviewed once, with the interviews lasting between 30 and 60 minutes. Six of the interviews were conducted at the teachers' schools and one at a public meeting place. All interviews were tape-recorded and transcribed by the lead author for coding purposes. Additionally, the lead author was able to observe each teacher teaching at least one class, and to examine each teacher's corresponding lesson plan.

\section{Data analysis}

A thematic analysis was employed to identify frequently occurring themes and patterns (Creswell, 2007; Glesne, 2011). Each author individually coded the transcripts and they were cross-referenced. In total, 30 codes were generated using a descriptive coding process (Saldaña, 2009). We composed these codes using the transcribed comments from the social studies teachers, the field notes created during observations, and the corresponding lesson plans. Afterwards, the codes were categorized into three emerging themes: (1) theoretical understanding of literacy; (2) application of literacy strategies; and (3) assessment of student literacy skills. We then began looking for examples in the data to describe each of the aforementioned themes.

This qualitative study analysed how seven secondary social studies teachers defined literacy in their social studies classroom. Furthermore, we sought to identify how the teachers' self-reported and observed pedagogical choices aligned with their definitions of literacy. Although only seven teachers participated in this study, and thus no generalizations can be made regarding these perspectives, we believe educators and teacher educators can utilize these perspectives, and subsequent pedagogical choices, to elicit rich discussion about literacy in the social studies classroom.

\section{Participants}

We utilized a snowball approach to recruit social studies teachers. That is, after first reaching out to teachers we were familiar with through professional associations, we asked participants to recommended other social studies teachers who they believed would be interested in participating in a study about literacy. In total, seven social studies teachers agreed to participate in the study. All seven teachers resided in a midsize, south-western city. Six of the teachers taught in a high school, while one taught in a middle school. Additionally, they represented three school districts.

Four of the participants were white women; the other three were white men. The teaching experience of the participants ranged from 1 to 20 years. The mean years of teaching experience was approximately 8 and the median was 6 . Table 1 provides a more nuanced list of all the participants (placed alphabetically based on their pseudonyms). 
Table 1: Background information on participants

\begin{tabular}{|c|c|}
\hline Participant & Background Information \\
\hline Beatrice & $\begin{array}{l}\text { A white, female teacher who teaches sixth-, seventh- and eighth-grade social } \\
\text { studies courses. She has been teaching for four years. She holds a bachelor's } \\
\text { degree in women's studies. After about } 12 \text { years working in other fields, she } \\
\text { returned to college to earn a post-bach in education. Since beginning her } \\
\text { teaching career, she had earned a master's degree in literacy and language. } \\
\text { She teaches in a school with a } 24 \text { per cent low-income student population, and } \\
\text { a majority white student population ( } 72 \text { per cent). }\end{array}$ \\
\hline Bobby & $\begin{array}{l}\text { A white, male special education teacher who co-teaches tenth-grade world } \\
\text { history with two different instructors. He has been teaching for six years but has } \\
\text { been in the special education department for the past two years. Previously, } \\
\text { he was in the social studies department. He holds a bachelor's degree in } \\
\text { geography with a minor in history. After about } 22 \text { years, he returned to college } \\
\text { to earn a post-bach in education. He teaches in a school with a } 40 \text { per cent } \\
\text { low-income student population, and a majority Hispanic student population } \\
\text { ( } 41 \text { per cent). }\end{array}$ \\
\hline Gloria & $\begin{array}{l}\text { A white, female teacher who teaches eleventh-grade advanced placement } \\
\text { (AP) US history. She has been teaching for seven years. She holds a bachelor's } \\
\text { degree in political science with a minor in history, and a master's degree in } \\
\text { history. She taught undergraduate history courses for two years while earning } \\
\text { her master's but eventually got a post-bach in education in order to start } \\
\text { teaching high-school history. She teaches in a school with a } 40 \text { per cent low- } \\
\text { income student population, and a majority Hispanic student population ( } 41 \\
\text { per cent). }\end{array}$ \\
\hline Greg & $\begin{array}{l}\text { A white, male teacher teaching ninth-grade pre-AP world geography and } \\
\text { tenth-grade AP human geography. He has been teaching for five years. He } \\
\text { holds a bachelor's degree in history education and had nearly completed his } \\
\text { master's degree in educational leadership. He teaches in a school with a } 22 \text { per } \\
\text { cent low-income student population, and a majority white student population } \\
\text { (62 per cent). }\end{array}$ \\
\hline Jasmine & $\begin{array}{l}\text { A white, female teacher teaching ninth-grade world geography, pre-AP } \\
\text { world geography and tenth-grade AP human geography. At the time of the } \\
\text { interview, she was finishing her first year of teaching. She holds a bachelor's } \\
\text { degree and a master's degree in history, and had just completed a master's } \\
\text { degree in education. She teaches in a school with a } 40 \text { per cent low-income } \\
\text { student population, and a majority Hispanic student population ( } 41 \text { per cent). }\end{array}$ \\
\hline Mark & $\begin{array}{l}\text { A white, male teacher teaching ninth-grade world geography and an elective } \\
\text { course on the Holocaust. In total, he has taught for } 20 \text { years, with the first } 7 \\
\text { years being at the elementary level and the last } 13 \text { years at the secondary level. } \\
\text { He holds a bachelor's degree in education with an emphasis on social studies. } \\
\text { He teaches in a school with a } 22 \text { per cent low-income student population, and } \\
\text { a majority white student population ( } 62 \text { per cent). }\end{array}$ \\
\hline Monica & $\begin{array}{l}\text { A white, female teacher teaching tenth-grade pre-AP world geography and } \\
\text { eleventh-grade AP US history. She has been teaching for } 14 \text { years. She holds } \\
\text { a bachelor's degree in history with a minor in anthropology. She teaches in } \\
\text { a school with a } 40 \text { per cent low-income student population, and a majority } \\
\text { Hispanic student population ( } 41 \text { per cent). }\end{array}$ \\
\hline
\end{tabular}




\section{Findings}

\section{Theoretical understanding of literacy}

We begin this analysis by examining the seven social studies teachers' theoretical understanding of literacy, that is, describing the ways they talked about and made meaning of literacy. We outline and describe four ways they talked about and defined literacy in the social studies classroom: (1) reading comprehension; (2) writing fluidity; (3) skills; and (4) vocabulary.

\section{Reading comprehension}

All seven teachers talked about literacy with regard to reading comprehension or reading for understanding. This was perhaps stated best by Mark: 'I constantly say to my students, the importance of reading is not necessarily for enjoyment; the importance of reading and literacy is to obtain understanding and to relay that understanding.' The texts they highlighted, however, varied. For example, five of the teachers expressed that students need to be able to read the textbook for understanding; two of the teachers wanted students to read more about current events and more secondary sources; and all the teachers mentioned or used primary sources (for example, texts, photographs, commercials, propaganda posters, political cartoons and maps). Additionally, reading for understanding meant more than simply filling in the blanks, as Jasmine said: 'For literacy, reading is being able to read something and understand its meaning, not just being able to gather facts, but what is the significance of it.'

\section{Writing fluidity}

Six of the seven teachers discussed writing fluidity as being a critical component of literacy. By writing fluidity, we mean, as Greg said, students 'being able to formulate their ideas and formulate the concepts in a way that they can put ... down on paper and make what they put down on paper understandable to everyone else'. We decided to use the term 'writing fluidity' based on two of the teachers, Jasmine and Monica, although we felt Monica summarized it best:

I want [students] to be fluent. I want them to transfer thought to writing based on any input or stimulus they have and vice versa. If they see something, I want them to be able to argue about it or write it down. If a thought occurs to them and they have a connection, I want them to go, 'oh, this is like that'. I want them to be fluent and fluid.

Yet, several of the teachers mentioned that practising writing is difficult and time consuming, and because of standardized tests, it does not have a large focus in their classrooms. Furthermore, Jasmine stated:

I think of it more as an English type of skill, being able to be a fluid writer, it is not something I attributed to the discipline. Though, I have recognized this year that it needs to be reinforced across the board. 


\section{Skills}

Five of the seven teachers discussed literacy in terms of a skill, that is, an ability at which students can excel or improve upon. More specifically within the social studies context, the teachers felt that students needed to have more practice with analysis, synthesis, questioning, argumentation and critical thinking. For example, Bobby defined literacy in the social studies this way:

It's the ability to analyse primary source documents, and to think critically in a historical context. Being able to look at whatever it is, secondary source or primary source, to be able to put themselves in that time frame and culture, and think critically of it. To be able to think from another person's perspective, or another time or culture.

Again, teachers considered that standardized testing prohibits practising these skills, as Gloria indicated: 'They don't even give us enough time to allow us to work on skills. A part of it is our new [assessment] because they are pushing rote-memorization so much.'

\section{Vocabulary}

Finally, four of the seven teachers spoke of vocabulary. In particular, the teachers expressed that students' vocabulary, or lack thereof, hindered reading comprehension, writing fluidity, and even participation with lectures and discussions. Beatrice stated, 'My whole philosophy on literacy in the social studies or history classroom, is that it's actually impossible to begin to understand these concepts if you don't have a really good grasp of the vocabulary.' Monica pointed out that the struggle with vocabulary goes beyond content-specific terms:

There are words that they don't know that I would consider very basic. I had a ninth-grader, and I was talking about social hierarchy the other day and the French Revolution, feudalism, limited social mobility, and I said the word 'ridge'. Someone asked me what it meant. I think you should know that by the time you're in high school. It's a deficit of more than just content [vocabulary].

So we found that, although none of the seven social studies teachers defined literacy in the same way, their theoretical understanding of literacy centred on reading comprehension, writing fluidity, skills, and vocabulary acquisition.

\section{Application of literacy strategies}

After examining the seven social studies teachers' theoretical understanding of literacy, we then began to identify specific literacy strategies they talked about utilizing in their instruction. Although there were numerous strategies discussed and observed, we found that they could be categorized in four ways: (1) content area reading strategies; (2) disciplinary reading strategies; (3) writing strategies; and (4) dialogue strategies.

\section{Content area reading strategies}

Of all the strategies they discussed, those centred on reading (whether content area or disciplinary) dominated the conversations. All seven teachers described using both content area reading and disciplinary reading strategies, although content area reading strategies $(n=31)$ were discussed more frequently than disciplinary reading 
strategies ( $n=15)$. For example, the three most common strategies that teachers discussed utilizing were Cornell or guided notes $(n=8)$, graphic organizers $(n=5)$ and anticipation guides $(n=4)$. Figure 1 shows the additional content area strategies the teachers described or were observed using. Moreover, we also found that the majority of the participants utilized a small number of strategies with great regularity, as is exemplified by Monica:

I give out a reading guide at the beginning of each unit that details what sections they are to read, when there will be a quiz on it, and what strategies to use to understand the material. Like, 'On this page it is best if you used a T-chart, on this section it is best if you did a Venn, [and] in this section it is best if you did Cornell notes.'

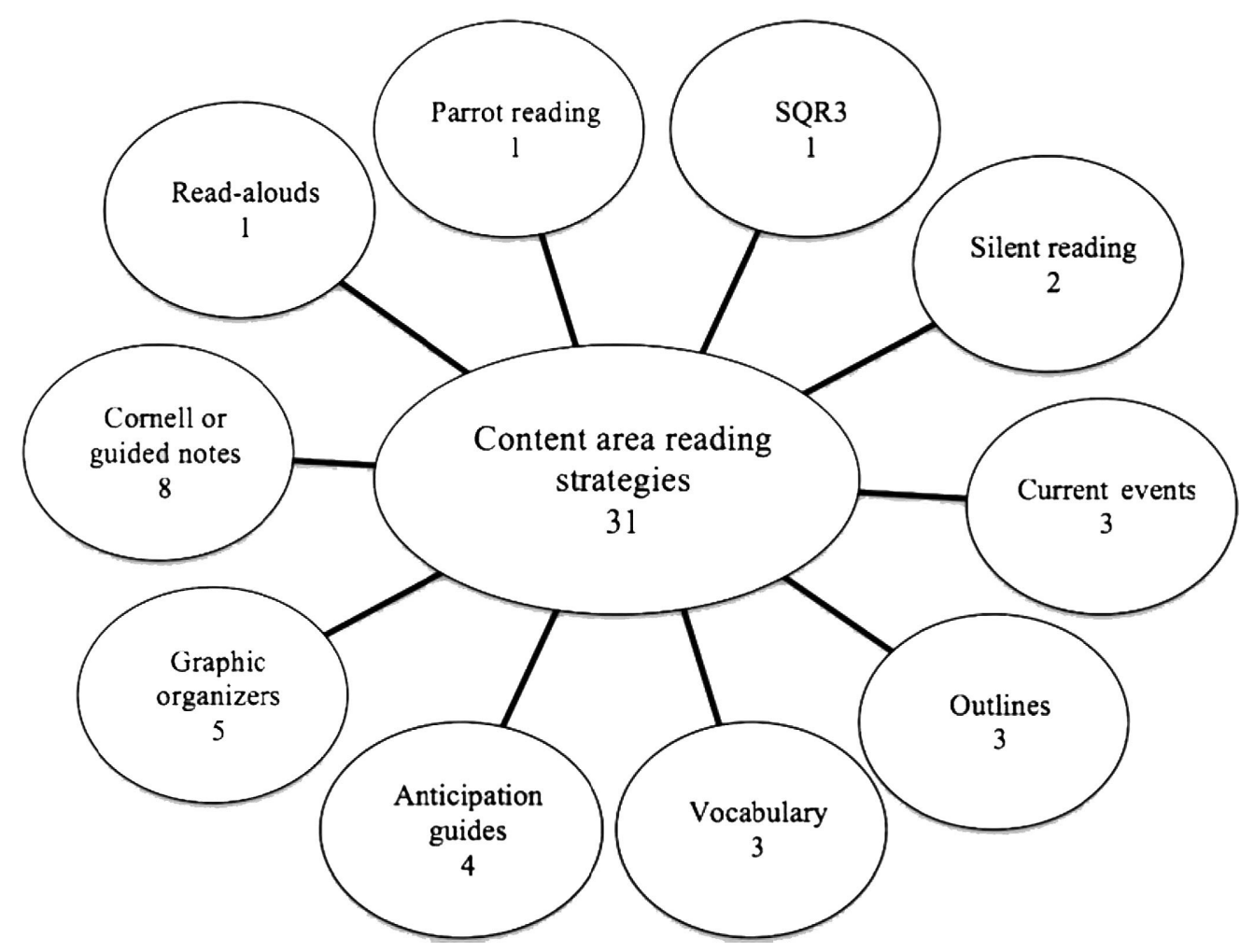

Figure 1: Content area reading strategies that teachers identified teaching

\section{Disciplinary reading strategies}

Figure 2 identifies the disciplinary reading strategies that teachers described using. In total, the teachers discussed these strategies less frequently than content area reading strategies. Yet, disciplinary reading strategies were most often discussed alongside writing activities; as Jasmine said, 'With AP, [and] their research paper, I talk to them about sourcing.' 


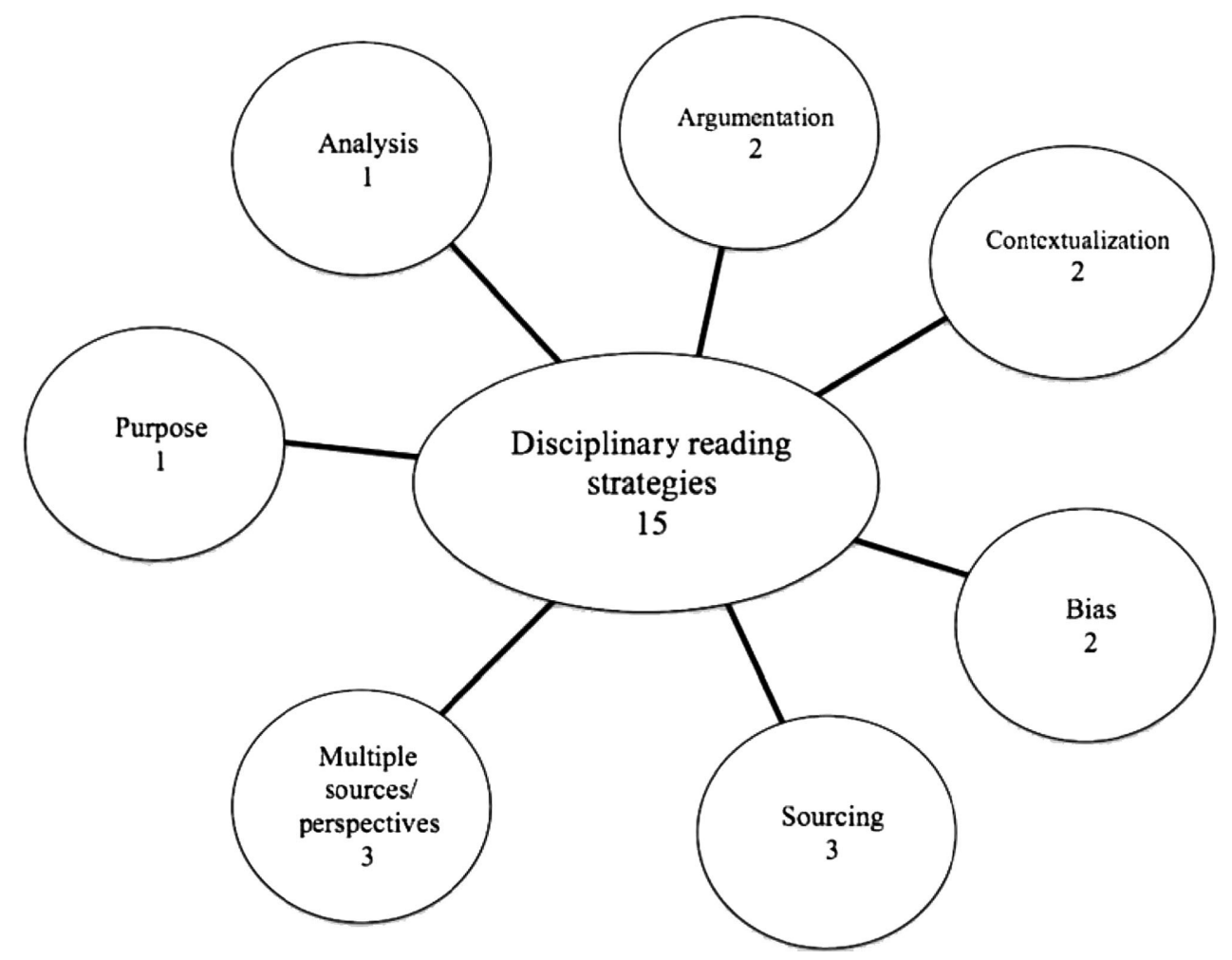

Figure 2: Disciplinary reading strategies that teachers identified teaching

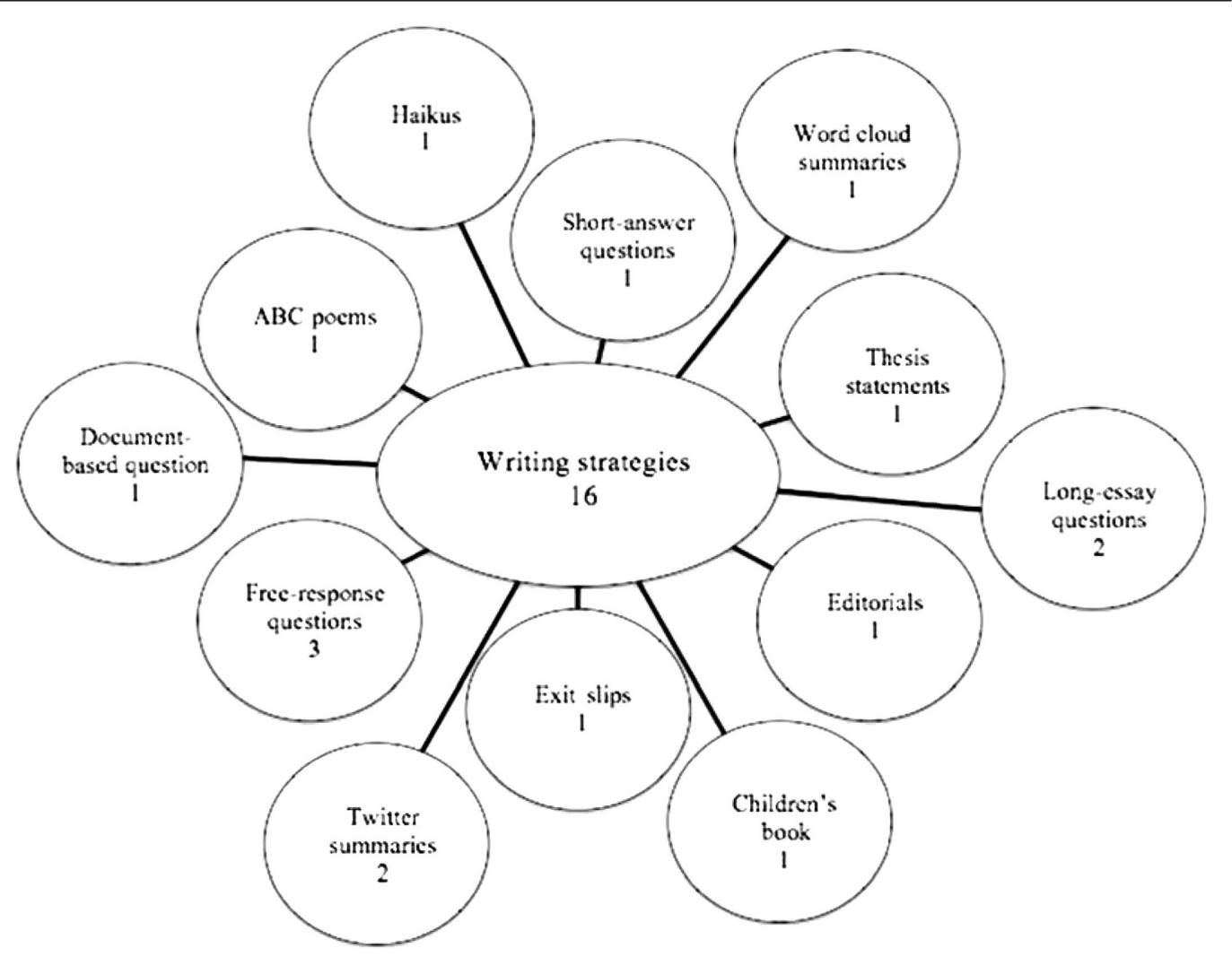

Figure 3: Writing strategies that teachers identified utilizing 


\section{Writing strategies}

Although it was true that disciplinary reading strategies were often connected with writing activities, it was not the case that all writing strategies focused on disciplinary literacy concepts. In total, the seven social studies teachers described or were observed using 16 writing strategies. Figure 3 provides a detailed list. Only once was a research paper mentioned. Every teacher who taught a college-level course, or advanced placement (AP) course, expressed that the majority of the writing strategies they utilized were focused on the formats used in the AP exams. As Gloria states, 'I've done a lot of different stuff, but with a change in our AP focus this year, we just don't have as much time.' When describing how much writing students complete in her class, Gloria later says, '[Short-answer questions], more than anything, they've had about one every one to two weeks. I want it every week, but the grading takes forever. [Document-based questions], three in the next four weeks, and [long-essay questions] two in the next six weeks.'

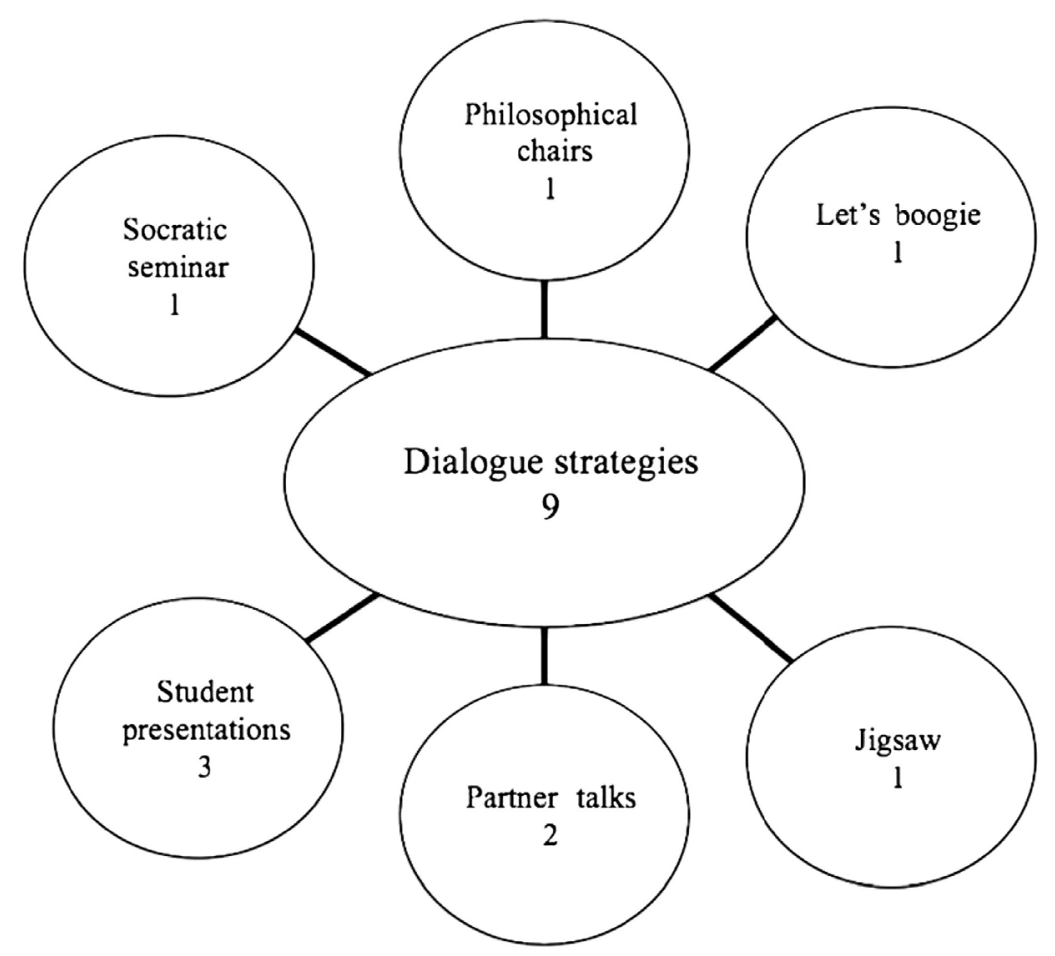

Figure 4: Dialogue strategies that teachers identified utilizing

\section{Dialogue strategies}

Teachers discussed dialogue strategies the least (see Figure 4). We included them, however, because we realized that teachers used these strategies often in conjunction with a reading activity. Therefore, teachers often had students read and then have partner talks about their reading. In addition, dialogue strategies were often used to help students practise their thinking and reasoning abilities. Still, consistency and efficiency were hurdles when attempting to utilize dialogue strategies, as Monica told us:

Then we compared to pre-revolutionary France, this is the feudal system, it's medieval, [and] it's in France. This system is what led to starving people who revolted but this same system is operating in England and yet that's 
where the Industrial Revolution starts. So, how do you have the same system, essentially, in Europe producing food that leads to revolution and despotic rule here but it's the path to enlightenment and production here. I said, talk to your partner and answer it. A couple of kids were able to figure out that it was the political response to an economic crisis that was the difference. [But] one class started talking about whether or not, if you can't get food from the ground should you get bugs, and so that led to 'how many crickets does it take to get this many calories versus how many grasshoppers. Have you ever tried bugs in a taco?' and it went that way.

\section{Assessment of student literacy skills}

The final theme we found in the data dealt with assessment of student literacy skills. This refers to the process of collecting, analysing and interpreting information from multiple sources for measuring student achievement with regard to their literary abilities. We found that outside assessments (for example, end-of-course exams, AP exams and high-stakes reading tests) greatly influenced the types of assessments these teachers utilized. As Monica lamented:

I'm not going to lie to you, I've been doing some of those lessons the entire time I've been teaching and the results I get these days are not the same as the results I used to get. It's not that the kids are bad. The kids are still good. They show up every day, they want to learn ... it's the focus of standardized testing.

Other teachers expressed similar sentiments, by noting either the format or the vast amount of content that needed to be covered as hurdles to teaching authentic literacy in their classrooms.

\section{Discussion}

Based on the findings in this study, there are a couple issues that deserve further discussion. First, while the seven social studies teachers defined literacy differently, their definitions included similar concepts. However, they were all unfamiliar with the term and concept of disciplinary literacy. Every teacher quickly and easily explained what they wanted students to be able to do with regard to reading and writing, but they all paused when asked to explain their expectations of students with regard to their discipline thinking. Some even asked for a definition and clarification. While at first we felt this was alarming, especially given that one of the teachers recently graduated with a master's degree in literacy and language, we understand that the term is relatively new in comparison to other literacy concepts, such as content area literacy. In fact, once given a definition, most teachers were able to acknowledge that they wanted students to be able to critically think, question perspectives and understand bias.

Thus, the problem does not seem to be a lack of theoretical understanding but a lack of understanding of ways to practically apply disciplinary literacy concepts. Unfortunately, this finding supports previous research, which suggests that content area instructors identify with being subject experts but do not consider disciplinary literacy practices to be part of their expertise (Hall, 2005). Indeed, much of the content area literacy strategies the teachers identified were learned during their teacher preparation training or as a result of professional development. While there are several groups designing, publishing and training social studies teachers to use disciplinary 
literacy techniques, such as the Stanford Historian Education Group, the Library of Congress and the DBQ Project, this study suggests that there is room for additional training,

Second, and perhaps most importantly, we found that the seven social studies teachers' understanding of literacy did not affect their pedagogical choices as much as the pragmatic nature of their jobs. That is, students needed to pass a course, and therefore the teachers needed to cover content and assess them according to an endof-course or AP exam. As a result, while there were content area reading, writing, and dialogue strategies employed, there were fewer attempts to ask students to showcase disciplinary habits of mind, as those were either not associated with the standardized test or were only a small component of a standardized test (for example, an AP exam). Every teacher lamented this truth, but perhaps Monica stated it best:

I want them to be fluent and fluid thinkers that they own information that they always have. I used to be good at that and I'm not anymore because I am fighting standardized testing because that is not what standardized testing tests. It tests can you pick ' $c$ ' better than you can pick 'b'. (emphasis in original)

Likewise, Bobby provides us with another perspective on the pragmatic barriers to a teacher's pedagogical choices - their students. Bobby was a special education teacher and, while he provides an adequate description of disciplinary literacy (even though he was unaware of the term), he was the only teacher not to describe writing fluidity as a major expectation for his students. Additionally, Bobby described himself as a co-teacher who offers academic assistance and guidance to students who are placed in 'regular' history courses but also have an Individual Education Plan.

\section{Conclusion}

Since there is minimal research on how social studies teachers make meaning of literacy in the social studies classroom, a few issues pertaining to this topic must be addressed. First, this study highlights how seven social studies teachers talked about, and incorporated, literacy in the social studies classrooms. To gain a better understanding of how social studies teachers make meaning of literacy, and how they can ensure their pedagogical choices align with that meaning, more research is needed on how secondary social studies teachers view literacy in their discipline.

Second, given the increased focus on disciplinary literacy, researchers need to focus on the pedagogical choices available to social studies teachers who wish to utilize a disciplinary literacy approach. In this study, all seven teachers described literacy in terms of reading comprehension, with a few including writing fluidity, skills and vocabulary; however, no teacher described discipline thinking or authentic dialogue. Is this consistent with other social studies teachers? What about pre-service teachers? Furthermore, how will teacher educators and professional development providers help social studies teachers, in-service and pre-service, begin to think of literacy with regard to a disciplined approach?

Every social studies teacher knows the importance of obtaining and understanding subject matter content knowledge. Social studies teachers can say the same for pedagogical content knowledge. Yet, few might take a similar stance with understanding and teaching a disciplinary literacy process. The question is, why? Social education researchers must engage with the aforementioned questions because 
understanding the disciplinary literacy process has an overwhelming pedagogical and educative influence on learning for both students and teachers.

\section{Notes on the contributors}

Joshua Kenna is an assistant professor of social science education at the University of Tennessee. Dr Kenna serves as a co-conference coordinator for the International Society for Social Studies. He earned his PhD in social science education at the University of Central Florida. He teaches social studies education courses, and taught high-school social studies before moving to higher education.

William B. Russell III is Professor of Education at the University of Central Florida. He teaches social science education courses, serves as the social science PhD track coordinator and is editor-in-chief of the most widely read research journal in the field, The Journal of Social Science Research.

Bonnie Bittman is a PhD candidate at the University of Central Florida. She has taught middle-school civics for a number of years in the central Florida area. She is currently working on her dissertation about AP social studies teachers and the teaching of controversial issues.

\section{References}

Alvermann, D.E. (2004) 'Multiliteracies and self-questioning in the service of science learning'. In Saul, E.W. (ed.) Crossing Borders in Literacy and Science Instruction: Perspectives on theory and practice. Newark, DE: International Reading Association, 226-38.

Baildon, M. and Damico, J.S. (2011) Social Studies as New Literacies in a Global Society: Relational cosmopolitanism in the classroom. New York: Routledge.

Bellino, M. (2008) 'Historical understanding and media literacy: A dispositional alignment'. International Journal of Social Education, 23 (1), 99-117.

Biswas, S. (2014) 'How to teach multiliteracies?'. Canadian Journal for Teacher Research, 3 July. Online. www.teacherresearch.ca/detail/post/how-to-teach-multiliteracies (accessed 14 September 2018).

Carney, M. and Indrisano, R. (2013) 'Disciplinary literacy and pedagogical content knowledge'. Journal of Education, 193 (3), 39-49.

Cope, B. and Kalantzis, M. (eds) (2000) Multiliteracies: Literacy learning and the design of social futures. London: Routledge.

Creswell, J.W. (2007) Qualitative Inquiry and Research Design: Choosing among five approaches. 2nd ed. Thousand Oaks, CA: SAGE Publications.

Damico, J., Baildon, M., Exter, M. and Guo, S.-J. (2009) 'Where we read from matters: Disciplinary literacy in a ninth-grade social studies classroom'. Journal of Adolescent and Adult Literacy, 53 (4), 325-35.

Draper, R.J., Smith, L.K., Hall, K.M. and Siebert, D. (2005) 'What's more important - literacy or content? Confronting the literacy-content dualism'. Action in Teacher Education, 27 (2), 12-21.

Fang, Z. and Coatoam, S. (2013) 'Disciplinary literacy: What you want to know about it'. Journal of Adolescent and Adult Literacy, 56 (8), 627-32.

Glesne, C. (2011) Becoming Qualitative Researchers: An introduction. 4th ed. Boston: Pearson.

Goudvis, A. and Harvey, S. (2012) 'Teaching for historical literacy'. Educational Leadership, 69 (6), 52-7.

Hall, L.A. (2005) 'Teachers and content area reading: Attitudes, beliefs and change'. Teaching and Teacher Education, 21 (4), 403-14.

Harste, J.C. (2003) 'What do we mean by literacy now?'. Voices from the Middle, 10 (3), 8-12.

Hynd-Shanahan, C. (2013) 'What does it take? The challenge of disciplinary literacy'. Journal of Adolescent and Adult Literacy, 57 (2), 93-8.

Ikpeze, C.H. and Boyd, F.B. (2007) 'Web-based inquiry learning: Facilitating thoughtful literacy with WebQuests'. Reading Teacher, 60 (7), 644-54. 
Kane, S. (2007) Literacy and Learning in the Content Areas. 2nd ed. Scottsdale, AZ: Holcomb Hathaway.

Kenna, J.L. and Russell, W.B. (2015) 'How did we get here? Common Core and the history of standards in social studies education'. In Turner, T.N., Clabough, J. and Cole, W. (eds) Getting at the Core of the Common Core with Social Studies. Charlotte, NC: Information Age Publishing, 5-24.

LaDuke, A., Lindner, M. and Yanoff, E. (2016) 'Content, disciplinary, and critical literacies in the C3 and Common Core'. Social Studies Research and Practice, 11 (3), 96-111.

Mason, L. and Metzger, S.A. (2012) 'Reconceptualizing media literacy in the social studies: A pragmatist critique of the NCSS position statement on media literacy'. Theory and Research in Social Education, 40 (4), 436-55.

McKenna, M.C. and Robinson, R.D. (1990) 'Content literacy: A definition and implications'. Journal of Reading, 34 (3), 184-6.

Moje, E.B. (1996) '"I teach students, not subjects": Teacher-student relationships as contexts for secondary literacy'. Reading Research Quarterly, 31 (2), 172-95.

Moje, E.B. (2008) 'Foregrounding the disciplines in secondary literacy teaching and learning: A call for change'. Journal of Adolescent and Adult Literacy, 52 (2), 96-107.

Moje, E.B., Ciechanowski, K.M., Kramer, K., Ellis, L., Carrillo, R. and Collazo, T. (2004) 'Working toward third space in content area literacy: An examination of everyday funds of knowledge and discourse'. Reading Research Quarterly, 39 (1), 38-70.

National Council of Teachers of English and International Reading Association (1996) Standards for the English Language Arts. Urbana, IL, and Newark, DE: NCTE and IRA.

National Governors Association Center for Best Practices and Council of Chief State School Officers (2010) Common Core State Standards: English language arts. Washington, DC: National Governors Association Center for Best Practices and Council of Chief State School Officers. Online. www.corestandards.org/ELA-Literacy/ (accessed 8 July 2018).

NCES (National Center for Education Statistics) (2007) The Nation's Report Card: Economics 2006 (NCES 2007-475). Washington, DC: Institute of Education Sciences.

NCES (National Center for Education Statistics) (2011) The Nation's Report Card: Reading 2011 (NCES 2012-457). Washington, DC: Institute of Education Sciences.

NCES (National Center for Education Statistics) (2013) The Nation's Report Card: A first look: 2013 mathematics and reading (NCES 2014-451). Washington, DC: Institute of Education Sciences.

NCES (National Center for Education Statistics) (2015) The Nation's Report Card: 2014 US history, geography, and civics at grade 8 (NCES 2015-112). Washington, DC: Institute of Education Sciences.

NCSS (National Council for the Social Studies) (1994) Expectations of Excellence: Curriculum standards for social studies. Washington, DC: National Council for the Social Studies. Online. https://files.eric.ed.gov/fulltext/ED378131.pdf (accessed 8 July 2018).

New London Group (1996) 'A pedagogy of multiliteracies: Designing social futures'. Harvard Educational Review, 66 (1), 60-92.

Nokes, J.D. (2013) Building Students' Historical Literacies: Learning to read and reason with historical texts and evidence. New York: Routledge.

O'Brien, D.G. and Stewart, R.A. (1990) 'Preservice teachers' perspectives on why every teacher is not a teacher of reading: A qualitative analysis'. Journal of Reading Behavior, 22 (2), 101-29.

O'Brien, D.G., Stewart, R.A. and Moje, E.B. (1995) 'Why content literacy is difficult to infuse into the secondary school: Complexities of curriculum, pedagogy, and school culture'. Reading Research Quarterly, 30 (3), 442-63.

O'Quinn, E.J. (2005) 'Critical literacy in democratic education: Responding to sociopolitical tensions in US schools'. Journal of Adolescent and Adult Literacy, 49 (4), 260-7.

Readence, J.E., Bean, T.W. and Baldwin, R.S. (2004) Content Area Literacy: An integrated approach. 8th ed. Dubuque, IA: Kendall Hunt.

Reehm, S.P. and Long, S.A. (1996) 'Reading in the mathematics classroom'. Middle School Journal, 27 (5), 35-41.

Reidel, M. and Draper, C. (2011a) 'Reading, democracy and secondary social studies education'. In Russell, W.B. (ed.) Contemporary Social Studies: An essential reader. Charlotte, NC: Information Age Publishing, 319-34.

Reidel, M. and Draper, C.A. (2011b) 'Reading for democracy: Preparing middle-grades social studies teachers to teach critical literacy'. Social Studies, 102 (3), 124-31.

Saldaña, J. (2009) 'An introduction to codes and coding'. In Saldaña, J. The Coding Manual for Qualitative Researchers. Los Angeles: SAGE Publications, 1-31. 
Shanahan, C., Shanahan, T. and Misischia, C. (2011) 'Analysis of expert readers in three disciplines: History, mathematics, and chemistry'. Journal of Literacy Research, 43 (4), 393-429.

Shanahan, T. and Shanahan, C. (2008) 'Teaching disciplinary literacy to adolescents: Rethinking content-area literacy'. Harvard Educational Review, 78 (1), 40-59.

Shanahan, T. and Shanahan, C. (2012) 'What is disciplinary literacy and why does it matter?'. Topics in Language Disorders, 32 (1), 7-18.

Shand, K., Winstead, L. and Kottler, E. (2012) 'Journey to medieval China: Using technologyenhanced instruction to develop content knowledge and digital literacy skills'. Social Studies, 103 (1), 20-30.

Shulman, L.S. (1986) 'Those who understand: Knowledge growth in teaching'. Educational Researcher, 15 (2), 4-14.

Shulman, L.S. (1987) 'Knowledge and teaching: Foundations of the new reform'. Harvard Educational Review, 57 (1), 1-22.

Simonson, S.D. (1995) 'A historical view of content area reading instruction'. Reading Psychology, 16 (2), 99-147.

Soares, L.B. and Wood, K. (2010) 'A critical literacy perspective for teaching and learning social studies'. Reading Teacher, 63 (6), 486-94.

Stein, L. and Prewett, A. (2009) 'Media literacy education in the social studies: Teacher perceptions and curricular challenges'. Teacher Education Quarterly, 36 (1), 131-48.

Street, B. (2003) 'What's "new" in new literacy studies? Critical approaches to literacy in theory and practice'. Current Issues in Comparative Education, 5 (2), 77-91.

Vacca, R.T. and Vacca, J.A.L. (2008) Content Area Reading: Literacy and learning across the curriculum. 9th ed. Boston: Pearson.

Walker, T.R. (2006) 'Historical literacy: Reading history through film'. Social Studies, 97 (1), 30-4.

Wineburg, S.S. (1991) 'Historical problem solving: A study of the cognitive processes used in the evaluation of documentary and pictorial evidence'. Journal of Educational Psychology, 83 (1), 73-87.

Zygouris-Coe, V.I. (2012) 'Disciplinary literacy and the Common Core State Standards'. Topics in Language Disorders, 32 (1), 35-50. 